\title{
Problems with adherence to treatment among adolescents with diabetes mellitus type 1
}

\author{
Mônica Rocha Pires', Raissa Cazzonatto de Figueiredo Bani'1, Graziele Zamineli de Lima1, \\ Maria Isabela Ramos Haddad², Patricia Mayumi Takamoto², Lúcia Alves da Rocha Pires ${ }^{3}$, \\ Márcia Marcondes Manganaro ${ }^{4}$, Márcia Regina Felippe Bueno Croscioli ${ }^{5}$, \\ Déborah Cristina Gonçalves Luiz Fernani ${ }^{6}$, Luiz Carlos Marques Vanderlei ${ }^{7}$, Ana Paula Coelho Figueira Freire ${ }^{8}$, \\ Francis Lopes Pacagnelli ${ }^{9}$
}

DOI: http://dx.doi.org/10.7322/jhgd.110023

\begin{abstract}
Introduction: Diabetes Mellitus type 1 (DM1) is a chronic degenerative disease with high impact on the lives of children and adolescents. The DM1 affects mainly children and young adults under 30 years old, with a predominance from 10 to 14 years old. As a chronic disease, involves changes in daily habits, being following the recommendations of health professionals one of the main conducts to achieve such changes, however, this follow-up is not easy and can directly influence the glycemic control and lead to complications.
\end{abstract}

Objective: Identify the difficulties of adolescent with DM1 to treatment adherence. The recommendations of this treatment are related to the blood glucose measurements, using a diet plan and insulin application.

Methods: The study included 15 adolescent with DM1, of both genders, aged 10-19 years participating in a multidisciplinary group at an outpatient unit in São Paulo, Brazil, aged 13,93 \pm 2.4 years, diagnosed with DM1 with an average time of 4.5 years. The following evaluations were employed:1) individual interviews for identification and clinical characterization; 2) characterization of cardiovascular and metabolic parameters; 2) anthropometric assessment and 4) application of a questionnaire with questions about problems of blood glucose measurements, diet plan and insulin application. Data collection was performed before medical appointment with an endocrinologist in a hospital in São Paulo state.

Results: The identified difficulties and cardio-metabolic variables showed the adolescents presented uncontrolled blood glucose levels, doing the rotation of insulin incompletely and face many daily difficulties to perform the appropriate treatment, being the most frequently reported the insulin application and proper nutrition.

Conclusion: Adolescents with type 1 diabetes presented difficulties in adherence to treatment, mainly o follow insulin treatment and proposals for changes in eating habits by following a diet. It is necessary that health professionals offer strategies and orientation to these individuals to improve the handling of their difficulties that directly affect the course of the disease and leave them more susceptible to developing complications.

Keywords: diabetes mellitus, lifestyle, health assessment, adolescent.

1 Graduada em Enfermagem - Universidade do Oeste Paulista - Presidente Prudente (SP), Brasil.

2 Graduada em Fisioterapia - Universidade do Oeste Paulista - Presidente Prudente (SP), Brasil.

3 Especialista em Pediatria e Neonatologia - Faculdade de Medicina de São José do Rio Preto, São José do Rio Preto (SP), Brasil.

4 Especialista em Educação e Avaliação do Ensino e da Aprendizagem; Docente do Curso de Enfermagem - Universidade do Oeste Paulista - Presidente Prudente (SP), Brasil

5 Mestre em Ciência Animal. Especialista em Enfermagem do Trabalho; Docente do Curso de Enfermagem - Universidade do Oeste Paulista - Presidente Prudente (SP), Brasil.

6 Mestre em Fisiologia do Esforço; Docente do Curso de Fisioterapia - Universidade do Oeste Paulista - Presidente Prudente (SP), Brasil.

7 Doutor em Ciências (Farmacologia); Docente do Curso de Fisioterapia da Universidade Estadual Paulista Julio Mesquita Filho - Presidente Prudente (SP), Brasil.

8 Mestre em Fisioterapia; Docente do curso de Fisioterapia Universidade do Oeste Paulista - Presidente Prudente (SP), Brasil.

9 Doutora em Biologia Celular e Estrutural; Docente do Curso de Fisioterapia e Orientadora do Mestrado em Ciência Animal - Universidade do Oeste Paulista - Presidente Prudente (SP), Brasil.

Corresponding author: Francis Lopes Pacagnelli. E-mail: francispacagnelli@unoeste.br

Suggested citation: Pires MR, Bani RCF, Lima GZ, Haddad, MIR, Takamoto PM, Pires LAR, et al. Problems with adherence to treatment among adolescents with diabetes mellitus type 1. J Hum Growth Dev. 26(1): 21-27. Doi: http://dx.doi.org/10.7322/jhgd.110023 Manuscript submitted: Oct 01 2015, accepted for publication Jan 2016. 


\section{INTRODUCTION}

Diabetes Mellitus is a metabolic disorder that occurs by several factors and is characterized by high level of glucose in the blood, which can occur as a result of the autoimmune destruction of pancreatic $\beta$ cells, gradually resulting in disability or partial absolute insulin in the body, or by tissue resistance to insulin action, which in both cases can lead to macro-and microvascular complications $^{1-2}$

In addition to the classic symptoms of diabetes, can result in acute and chronic complications. These acute complications differ of Chronicles by occur suddenly, constituting clinical emergencies, which should be identified and treated immediately. Acute complications correspond to hypoglycemia, Hyperglycemia and Diabetic Ketoacidosis. Chronic complications can be classified into macrovascular, microvascular and neuropathic, so the tracing of these complications should be carried out from five years of $^{3-4}$ diagnosis.

The incidence of Diabetes Mellitus is constantly growing and it is estimated that in 2025 will affect 5.4\% of the world's population ${ }^{5}$. For the Diabetes Mellitus type 1 (DM1) $0.5 \%$ of estimated new cases for every 100,000 inhabitants per year ${ }^{1}$. According to the Brazilian society of Diabetes ${ }^{6}$ currently exist in Brazil 100 thousand patients diagnosed with DM1 under 15 years of age and the index of the child population under 5 years is constantly growing.

The treatment of DM1 is mainly done through daily applications of insulin, because most of these guys have the pancreatic cells destroyed ${ }^{7}$. For the effective control of the disease treatment should occur correctly and through healthy living habits. However, this is a highly complex treatment, as it requires the adherence to treatment by the patient, combined with a balanced diet and physical exercise, to prevent the complications of diabetes in addition to improving the quality of life $\mathrm{e}^{8-10}$.

For planning health education to individuals with DM1 is recommended first assess and know their living conditions $^{8}$. For this to happen, it is necessary that health professionals be able to educate patients appropriately in different stages of life, so work should happen ${ }^{6}$ interdisciplinary.

Before the start of the process of education, the professional should identify the needs of the patient, such as culture, beliefs, family support, social and economic conditions. The practice of education should cover the clinical care, health promotion and advice, with the aim of increasing the knowledge of the disease, to influence a patient change behavior, for a clinical and metabolic improvement, to achieve a good quality of life in order to reduce and prevent chronic complications ${ }^{6}$. They see the importance that constitutes education actions and the DM1 is associated with several barriers not only in relation to the disease and its complications, as also related to health, for this team often play the role of educator, especially as regards the relevant issues of the patient, which must have a comprehensive individualized approach ${ }^{11}$.

Healthy habits for the individual with DM1 should be used daily by the capillary blood glucose control, insu- lin therapy and regular physical activity, which are considered of utmost importance to prevent and delay chronic and acute complications and hospitalizations ${ }^{12-13}$. That's why Marques, Fornés, Stringhini ${ }^{14}$ also stress that proper treatment for the control of acute episodes of Hyperglycemia or hypoglycemia can prevent the development of common diseases in those circumstances as Neuropathies, kidney diseases and cardiovascular diseases.

Is therefore the monitoring of the individual by a multidisciplinary team consisting of a doctor, a nurse, nutritionist, physiotherapist and psychologist ${ }^{5}$. Health professionals must recognize their abilities and have the duty to support and educate the adolescents and family to selfcare, to facilitate proper treatment ${ }^{15}$. It is evidenced that the stress of family that comes from the complex treatment of DM1 can generate a bad glycemic control in adolescence and, so if you see that the family must be ready to support and assist in adhesion of the ${ }^{16}$ treatment.

However, if the treatment is not attached correctly, the individual with DM1 may be diseases that lead to hospitalization, changes in the routine of daily life, school absences and risk of worsening the living conditions of future ${ }^{9}$. In addition, the adolescents face many emotional conflicts that can cause several psychological disorders and lead to poor adherence to treatment. The most common are the insecurity and suffering, since they feel apprehensive, not knowing if it will be accepted by the group ${ }^{17}$.

Another problem faced is the application of insulin and blood glucose capillary check every day, which usually cause great suffering for teens, which may result in failures in the hard treatment and consequently harm his treatment. The daily life of the adolescent with DM1 is transformed and differentiated by the disease, being necessary in many cases psychological monitoring ${ }^{17}$. Therefore, prevention is of paramount importance in order to avoid the complications of the disease through educational programs and family support ${ }^{9}$.

So, before constant complications and problems found in individuals with DM1 emerged the need to investigate the difficulties encountered by adolescents in adhering to treatment, for further actions related to their behaviors.

So the objective of this study is to identify the daily difficulties with adherence to treatment of adolescents diagnosed with Diabetes Mellitus type 1 mainly related to blood sugar measurement, nutrition plan and application of prescribed insulin.

\section{METHODS}

\section{Series}

This is a survey of epidemiological, descriptive and transversal character, with quantitative and qualitative approach.

The individuals participating in the study were 15 adolescents with Diabetes Mellitus type 1 (DM1), of both genders, aged 10 to 19 years old, participating in a multidisciplinary group composed of a nurse, nutritionist, physiotherapist and graduation students who participate in an outpatient clinic of a municipality in São Paulo, Brazil. 
Tabela 1: Description of the variables of young adolescents with type 1 diabetes mellitus in average and standard deviation values expressed, Presidente Prudente, SP. 2013

\begin{tabular}{cc} 
Parameters & $\mathbf{N}=\mathbf{1 5}$ \\
Sex (M/F) & $6 / 9$ \\
Age (years) & $14.93 \pm 2.4$ \\
Weight (kg) & $55.6 \pm 12$ \\
Height (m) & $1.61 \pm 0.09$ \\
BMI (kg/m²) & $21.2 \pm 3.2$ \\
SBP (mmHg) & $103 \pm 6.5$ \\
DBP (mmHg) & $67 \pm 10.9$ \\
HR (bpm) & $84 \pm 11.9$ \\
Duration of DM1 (months) & $54.5 \pm 48.1$ \\
Age of diagnosis (years) & $10.2 \pm 3.7$ \\
NPH insulin (Ul) & $53.3 \pm 51.2$ \\
Application frequency (times/day) & $2.06 \pm 0.7$ \\
AlC (\%) & $9.03 \pm 0.02$ \\
\hline
\end{tabular}

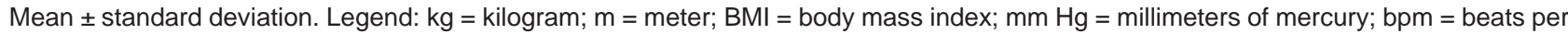
minute; IU = International Unit; A1C = glycated hemoglobin; SBP = systolic blood pressure; DBP = diastolic blood pressure; HR = heart rate; Recombinant human insulin $\mathrm{NPH}$.

The Group provides information such as the correct form of insulin application (local, castors), the importance of glycemic control in preventing complications, physical exercise and its specific characteristics (intensity, duration and frequency), foot care and tips for a healthy diet. These guidelines are provided in oral form with use of banners, brochures, posters and Conversation Map Kit ${ }^{\mathrm{TM}}$ (Diabetes Conversations).

Were included in the survey the adolescents who showed cognitive and understanding conditions to answer questionnaires, accompanied by parents or guardians who agreed voluntarily to participate in the research.

\section{Ethical aspects}

This research has the approval of the Research Ethics Committee of the University of the West of São Paulo, under the 1643 and Protocol is in line with the resolution 466/2012 from the National Health Council.

\section{Procedures}

The data collection took place during the period from August to October 2013 in the outpatient clinic of a municipality in São Paulo, Brazil. The participants were approached individually after the guidelines of multidisciplinary group and prior endocrinological consultation, being understood as the ethical aspects and relevance of the research. The evaluation Protocol was composed of four steps: individual interviews to identification and characterization, clinical characterization of the cardiovascular and metabolic parameters, anthropometric assessment and questionnaires about difficulties. Initially the volunteers were identified through direct interview with questionnaires developed for this purpose, consisting of name, age, gender, insulin in use (dose). For cardiovascular and metabolic characterization were acquired informations from the individual's medical record, always the last doctor's appointment, with values of blood pressure, heart rate and glycated hemoglobin.

\section{Analysis of experienced difficulties}

Was applied through a direct interview questionnaire (multiple choice and open questions) built by researchers, for evaluation of experienced difficulties in the daily lives of diabetic individual. In this questionnaire were addressed the feelings to find the disease, daily difficulties as regards therapeutic recommendations prescribed for the treatment of diabetes. Such recommendations related, more specifically, to the measurement of blood sugar, eating plan and application of insulin, feeling with regard to complications and feeling about the insulin-therapeutic treatment. The open-ended questions gave rise to the categories in which it was considered the benchmark of Morse and Field that is intended to categorize the data according to the response of the individual ${ }^{19}$. Were prepared two thematic units divided into two categories for each unit, being they: Perception of individuals in relation to artemether-lumefantrine,-category: feelling free to apply insulin and not feelling the urge to apply insulin; Perception of individuals in relation to the complications of the disease, -category: being afraid/concerned about the complications of the disease and not to being afraid/concerned about the complications of the disease.

Adolescents surveyed were identified by the initial letter D corresponds to the word Diabetes to guarantee confidentiality and anonymity during the tabulation and display lines. The quantitative data were analyzed by descriptive statistics and figures were presented as mean \pm standard deviation, and percentage values.

\section{RESULTS AND DISCUSSION}

The sample was composed of 15 adolescents, females showed up more often with $60 \%(n=9)$. In table 1 are the anthropometric characteristics, and cardio-metabolic care clinics for the treatment of insulin-therapeutic adolescents with diabetes mellitus type 1 (DM1).

As for the percentile of body mass index (BMI)/Age of volunteers examined 03 were classified 
cieties choose to adopt A1C goals with smaller values as $6.5 \%$, precisely to avoid the exceeding of the neighboring values $^{2}$

The capillary blood glucose test was marked by $87.7 \%$ of the respondents, $33.3 \%$ do it three times a day; $26.7 \%$ four times; $26.7 \% 13.3 \%$ five times and six times a day when questioned about who makes application of insulin $53.3 \%$ said if auto apply, $13.3 \%$ reported to be made by parents and $33.3 \%$ reported to be made by parents and self application.

As for the rotation of the application places $80 \%$ of adolescents perform the castor and $20 \%$ said no, what confirms with data from other studies show that skin complications arising from the application of insulin are more prevalent in adolescents, causing damage to the glycemic control ${ }^{21}$.

In relation to application places, 13 adolescents reported insulin in the abdomen, 08 in the arm, 12 in the leg and 2 in the gluteus. The regions recommended for application of subcutaneous insulin are the posterior aspect of the arm, abdominal wall, the anterior surface of the thigh and gluteus external upper quadrant, being that these re- gions present different absorption time between them. The choice for the application area may be related to various factors such as the emotional state, age, and physical activity lipo-hypertrophy ${ }^{21}$.

It is important that educational interventions are carried out by the health team, since these actions are reflected directly in the field of Public Health, especially with regard to enhancing the importance to the rotation of the insulin application places and the damage arising from non-adherence to the rotation, to avoid common complications such as hematoma and lipo-hypertrophy. These changes may result in decreased insulin absorption, and consequently impair glycemic control and may lead the individual to a serious hyperglycemic crisis. The lipo-hypertrophy causes that the skin area becomes hardened and lose sensitivity, which is one of the factors by which individuals prefer to apply always in the same area ${ }^{21}$.

The difficulties experienced by adolescents were classified according to their answers and are described in Table 2.

Table 2: Responses to the questionnaire on the difficulties experienced in the daily lives of adolescents with Type 1 Diabetes Mellitus, Presidente Prudente, SP. 2013

\begin{tabular}{|c|c|c|c|c|c|}
\hline 1. feeling to find that you have DM1 & Fear & accepted & Revolt & Fear and anger & \\
\hline & 8 & 2 & 4 & 1 & \\
\hline \multirow[t]{2}{*}{ 2. Difficulty in daily to have DM1 } & Apply insulin & $\begin{array}{l}\text { Test glicemy } \\
\text { capillary }\end{array}$ & Blood glucose & Insulin and food & Others \\
\hline & 50 & 1 & 5 & 2 & 2 \\
\hline \multirow[t]{2}{*}{ 3. Difficulty in accepting the disease } & Yes & No & & & \\
\hline & 7 & 8 & & & \\
\hline
\end{tabular}

\section{Perception of individuals in relation to drug treat- ment}

\section{Category: Feelling free to apply insulin}

This category reflects the awareness of six of the fifteen individuals from research with regard to the application of insulin. They recognize that to stay well and live better is necessary the application of insulin.

"I believe that taking it will make me feel better and allow me to live the daily routine" (D1);

"It doesn't hurt as much, is quick to implement, but it bothers a little" (D2);

"I'm used to it" (D3 and D4).

It is noticeable that this understanding is reflected in the self-care demonstrated in insulin therapeutic treatment, in which thirteen of the fifteen adolescents surveyed said make the application of insulin regularly, which makes the adolescent care more about issues related to his treatment, favoring the maintenance of their self-care.

This condition of acceptance reflects the understanding of the adolescent about the consequences of not following the prescribed treatment, demonstrating awareness that this condition is not always incompatible with his lifestyle ${ }^{22}$.

\section{Category: not feelling free to apply insulin}

While the previous category portrays the free feeling to apply insulin, this category expressed the opposite, demonstrating the difficulties and feelings found in this practical moment of treatment for nine of the fifteen respondents.

"I feel uncomfortable, sad" (D5);

"It hurts, I'm scared" (D6);

"Because it hurts and it's uncomfortable. Can never forget (D8)";

"Very uncomfortable" (D9);

"Can't get over" (D10);

"I take insulin, but the fact of taking it every day bothers me" (D11).

"It causes pain" (D12)

It is possible to see in the accounts that some adolescents feel inconvenienced by having to make use of insulin, and have feelings of sadness, and even reluctance for having DM1. It shows that common procedures to the daily life of diabetics as the capillary blood glucose testing and insulin application, are perceived as stressful and undesirable situations, what evidence the non-acceptance of the disease and the treatment. 
Apply insulin and an increase in the number of daily applications is a source of great suffering for the individual ${ }^{22}$. Suffering from not feel at ease during the application of insulin, may be related to non-acceptance of the condition of the individual with DM1, which occurs mainly among adolescents, since the disease is often perceived as something that imposes limitations, due to his permanent condition $^{21}$. The pain felt during the application of insulin is something annoying, which can consequently impede the proper management of the disease, helping adolescents avoid or create resistance in these moments. ${ }^{12 .}$

\section{Perception of individuals in relation to the com- plications of the disease}

\section{Category: being afraid/concerned about the com- plications of the disease}

This category reflects the concern with the complications of DM1 in ten teens.

"The complications and some injury in some organ scare me" (D14);

"My grandfather and grandmother had diabetes, my maternal grandmother passed away from complications" (D1);

"Because I'm scared I won't be able to live long enough" (D5);

“Oh, because I'm afraid of going blind or happen other things" (D3);

"I'm scared to play and pass out" (D7);

"Because of the risks such as infections or amputations, for example," (D2);

"Because it has several risks" (D8);

"Because of various cases" (D13);

"Yes, it could happen tomorrow" (D10).

"Because diabetes is something that if you're not careful you can cause many complications (D11).

Upon the testimony described, it is possible to observe that adolescents understand that DM1 offers risks and complications. They do not express concretely what are these risks and are based on comparing with other cases which makes us understand that most adolescents do not have the size and exact knowledge of what is the DM1, its complications, and what are its risks specifically. From there it is understood that the feelings of fear are consequent to lack of information and non-acceptance of the disease, which can be associated with the lack of family support and absence of the health team.

These feelings can also be related to parents ' behavior, especially when these are not able to deal with the situation of disease, or when present difficulties in accepting the child diabetes. This can influence negatively the adaptation of the adolescent in relation to diabetes, cooperating or not with the disease control ${ }^{9-15}$. The family then worry in an exaggerated manner, and to convey feelings of anxiety and fear in relation to immediate and late complications of the disease, not only when the adolescent doesn't follow treatment properly, causing the same feel and think the same way ${ }^{22}$.

In this regard, we should mention that the DM1, decreases in average until 15 years life expectancy, currently the most common cause of blindness, chronic kid- ney disease and amputation of lower limbs by non traumatic causes ${ }^{9}$

The World Health Organization (WHO) has shown in figures the consequences of this disease after 15 years of your course in the body, with estimated that $2 \%$ of individuals affected will be blind, and of $30 \%$ to $45 \%$ will have some degree of retinopathy, $10 \%$ to $20 \%$ will develop nephropathy, $20 \%$, to $35 \%$ will develop neuropathy and $10 \%$ to $25 \%$ will have developed cardiovascular disease. This can lead to a worsening of quality of life that affects not only the individual, but also his family, therefore, the need for clarification, information, awareness and participation ${ }^{9}$ family

\section{Category: Not being afraid/concerned about the complications of the disease}

The attitudes of adolescents with DM1 can go of conformity to self-care. This tends to happen when the family becomes involved with the disease and becomes part of the daily care of individuals with diabetes ${ }^{9}$. In this category five adolescents reported having no concern or fear of future complications.

"Why wanted me to take care to avoid" (D4).

The expression of this talk allows the representation of this category, because teens who claim to not be afraid with regard to complications of DM1 are those who understand their diabetic condition, and understand that this is a disease that requires dedication and responsibility, but that doesn't stop you from living a life common to other adolescents, without excessive suffering, denial and stress, but understand that investing in your self-care will bring you benefits in the future.

It is noted that the family is very important in the treatment of adolescents with diabetes, by offering support in lived situations either good or bad, what makes the individual feel more prepared to deal with the disease and its complications, by turning over time feelings of fear, denial and despair, acceptance of their condition by means of adaptation mechanisms 9 .

With this study it was possible to identify that adolescents with Diabetes Mellitus type 1 (DM1) face several daily difficulties to perform the proper treatment, and the most difficult ones are the application of insulin and proper nutrition.

At the beginning of the treatment of DM1 the individual should make changes in his routine, requiring new life habits such as regular physical activity, proper nutrition, use of insulin and blood glucose capillary test, however the most difficult change is the acceptance of the condition of the disease, which must be accompanied by their family and aided by a multidisciplinary team ${ }^{23,24}$.

Due to the fact of to have to adopt changes in their daily life routine, some individuals end up adapting to this situation and understanding the importance of treatment ${ }^{17}$. After analyzing the responses of teens surveyed by questionnaire on the difficulties experienced in daily life, it was identified that half had difficulty in accepting the disease, and most reported revolt and fear before the discovery of DM1. (Table 2)

Adolescents with DM1 pass through barriers that comes from great efforts to keep a proper control of the 
disease, being the main barriers considered as painful ones and routine as the capillary blood glucose testing and insulin application, which often causes anxiety and discomfort to the individual. Another barrier that is also present in the daily life of these adolescents is related to get adequate nutrition for the DM1, which is still seen as a challenge, because they fight often against the desire of common food consumption for non-diabetic teens offered at school and other public places ${ }^{12}$. In this study, twelve of the fifteen adolescents were the main difficulty in daily insulin application and proper nutrition.

In conclusion, the main difficulties encountered in the daily treatment of adolescents with DM1 refer to application of insulin and food. These two difficulties pointed out are of great importance for the maintenance and control of the disease. So, it is hoped that this study will help to inform the health staff about the main difficulties related treatment of DM1 pointed out by adolescents, aiming at a more appropriate disease management by multidisciplinary team for consequent improvement of quality of life and reduction of future damages. It is important to note that feelings against the acceptance of the Diabetes Mellitus type 1 (DM1), such as fear and anger, were present at the time of the discovery of the disease, alerting the importance of family and multidisciplinary team as the pillars to support the adolescent in the discovery of the disease and extending this support to every stage of treatment.

\section{ACKNOWLEDGEMENT}

University of the West of São Paulo by institutional incentives (protocol number: 1643/ PROBIC).

\section{REFERENCES}

1. Sociedade Brasileira de Diabetes. Diagnóstico e tratamento do diabetes tipo 1. São Paulo: SBD; 2012; p. 6-18.

2. Chhabra P, Brayman KL. Stem cell therapy to cure type 1 diabetes: from hype to hope. Stem Cells Transl Med. 2013; 2(5): 328-36. DOI: http://dx.doi.org/10.5966/sctm.2012-0116

3. Alves RL, Freitas FM, Fernandes ASN, Ferraz SC, Silva E, Corrêa CL, et al. Modulação autonômica e capacidade funcional em indivíduos portadores de diabetes mellitus do tipo 1 e 2. J Hum Growth Dev. 2012; 22(3): 321-7. DOI: http://dx.doi.org/10.7322/jhgd.46396

4. Cobas RA, Gomes MB. Diabetes Mellitus. Rev Hosp Universitário Pedro Ernesto. 2010; 9(supl. 1): 69-74.

5. Brasil. Ministério da Saúde. Secretaria de Atenção à Saúde. Departamento de Atenção Básica. Diabetes Mellitus: cadernos de atenção básica. Brasília: Ministério da Saúde; 2006; p. 9-41.

6. Sociedade Brasileira de Diabetes. Diretrizes da sociedade brasileira de diabetes. São Paulo: SBD; 2009; p. 23-171.

7. Wu YL, Ding YP, Gao J, Tanaka Y, Zhang W. Risk factors and primary prevention trials for type 1 diabetes. Int J Biol Sci. 2013; 9(7): 666-79. DOI: http://dx.doi.org/10.7150/ijbs.6610

8. Torres HC, Amaral MA, Amorim MM, Cyrino AP, Bodstein R. Capacitação de profissionais da atenção primária à saúde para educação em Diabetes Mellitus. Rev Acta Paul Enferm. 2010; 23(6): 751-6. DOI: http://dx.doi.org/10.1590/S0103-21002010000600006

9. Leal DT, Fialho FA, Dias IMAV, Nascimento L, Arruda WC. Diabetes na infância e adolescência: o enfrentamento da doença no cotidiano da família. HU Rev. 2009; 35(4): 288-95.

10. Yardley J, Mollard R, Macintosh A, Macmillan F, Wicklow B, Berard L, et al. Vigorous intensity exercise for glycemic control in patients with type 1 diabetes. Can J Diabetes. 2013; 37(6): 427-32. DOI: http://dx.doi.org/10.1016/j.jcjd.2013.08.269.

11. Kienle GS, Meusers M, Quecke B, Hilgard D. Patient-centered diabetes care in children: Na integrated, individualized, systems-oriented, and multidisciplinary approach. Glob Adv Med Health. 2013; 2(2): 12-9. DOI: http://dx.doi.org/10.7453/gahmj.2013.005

12. Nascimento LC, Amaral MJ, Sparapani VC, Fonseca LMM, Nunes MDR, Dupas G. Diabetes mellitus tipo 1: evidências da literatura para seu manejo adequado, na perspectiva de crianças. Rev Esc Enferm USP. 2011; 45(3): 764-9. DOI: http://dx.doi.org/10.1590/S0080-62342011000300031

13. Demirel F, Tepe D, Kara O, Esen I. Microvascular complications in adolescents with type 1 Diabetes Mellitus. J Clin Res Pediatr Endocrinol. 2013; 5(3): 145-9. DOI: http://dx.doi.org/10.4274/Jcrpe.994

14. Marques RMR, Fornés NS, Stringhini MLF. Fatores socioeconômicos, demográficos, nutricionais e de atividade física no controle glicêmico de adolescentes portadores de diabetes melito tipo 1. Arq Bras Endocrinol Metab. 2011; 55(3): 194-202. DOI: http://dx.doi.org/10.1590/S0004-27302011000300004

15. Spencer JE, Cooper HC, Milton B. The lived experiences of young people (13-16 years) with type 1 diabetes mellitus and their parents - a qualitative phenomenological study. Diabet Med. 2013; 30(1): e17-24. DOI: http://dx.doi.org/10.1111/dme.12021

16. Tsiouli E, Alexopoulos EC, Stefanaki C, Darviri C, Chrousos GP. Effects of diabetes-related family stress on glycemic control in youg patients with type 1 diabetes: Systematic review. Can Fam Physician. 2013; 59(2): 143-9. 
17. Fragoso LVC, Araújo MFM, Lima AKG, Freitas RWJF, Damasceno MMC. Vivências Cotidianas de Adolescentes com Diabetes Mellitus Tipo 1. Texto Contexto Enferm. 2010; 19(3): 443-51.

18. Organização Mundial da Saúde (OMS). Sisvan: vigilância alimentar e nutricional. Curvas de crescimento. 2007; p. 37.

19. Field PA, Morse JM. Nursing research: the application of qualitative approaches. Rockville: Aspen Publication. 1985; p. 1-17.

20. Pimazoni Netto A, Andriolo A, Fraige Filho F, Tambascia M, Gomes MB, Melo M, et al. Atualização sobre hemoglobina glicada (HbA1C) para avaliação do controle glicêmico e para o diagnóstico do diabetes: aspectos clínicos e laboratoriais. J Bras Patol Med Lab. 2009; 45(1): 31-48. DOI: http://dx.doi.org/10.1590/ S1676-24442009000100007

21. Alencar AMPC, Silva MJ, Damasceno MMC, Freitas RWJF, Araújo MFM. Complicações da pele relacionadas à aplicação da insulina: um estudo exploratório. Rev Min Enferm. 2010; 14(1): 75-81.

22. Damião EBC, Dias VC, Fabri LRO. O adolescente e o diabetes: uma experiência de vida. Acta Paul Enferm. 2010;23(1): 41-7. DOI: http://dx.doi.org/10.1590/S0103-21002010000100007

23. Giordano C, Amato MC, Ciresi A, Citarrella R, Mantione L, Accidenti M, et al. Predictors of microvascular complications in type 1 diabetic patients at onset: The role of metabolic memory. Eur J Intern Med. 2011; 22(3): 266-74. DOI: http://dx.doi.org/10.1016/j.ejim.2011.02.009.

24. Ramos L, Ferreira EAP. Fatores emocionais, qualidade de vida e adesão ao tratamento em adultos com diabetes tipo 2. Rev Bras Crescimento Desenvolv Hum. 2011; 21(3): 867-77.

This article is distributed under the terms of the Creative Commons Attribution 4.0 International License (http://creativecommons.org/licenses/by/4.0/), which permits unrestricted use, distribution, and reproduction in any medium, provided you give appropriate credit to the original author(s) and the source, provide a link to the Creative Commons license, and indicate if changes were made. The Creative Commons Public Domain Dedication waiver (http://creativecommons.org/publicdomain/zero/1.0/) applies to the data made available in this article, unless otherwise stated.

\section{Resumo}

Introdução: O diabetes mellitus Tipo 1 (DM1) é uma doença crônico-degenerativa de grande impacto na vida de crianças e adolescentes. O DM1 acomete, principalmente, crianças e adultos jovens com idade inferior a 30 anos, com predomínio dos 10 aos 14 anos. Como uma doença crônica, envolve mudança nos hábitos cotidianos, sendo o seguimento das recomendações dos profissionais de saúde um dos principais comportamentos para se alcançar tais mudanças, entretanto, este seguimento não é fácil e pode repercutir diretamente no controle glicêmico e ocasionar complicações.

Objetivo: Esta pesquisa teve por objetivo identificar as dificuldades que adolescentes com diagnóstico de DM1 relatam para seguirem as recomendações terapêuticas prescritas para o tratamento do diabetes. Tais recomendações dizem respeito, mais especificamente, à mensuração da glicemia, utilização do plano alimentar e aplicação de insulina.

Método: Participaram do estudo 15 adolescentes com DM1, de ambos os sexos, na faixa etária de 10 a 19 anos, que participam de um grupo multidisciplinar em um ambulatório de um município, no interior do Estado de São Paulo, com idades de 13,93 \pm 2,4 anos, diagnosticados com DM1, em média há 4,5 anos. Foram utilizadas as seguintes avaliações: 1) entrevistas individuais para identificação e caracterização clínica; 2) caracterização dos parâmetros cardiovasculares e metabólicos; 2) avaliação antropométrica e 4) aplicação de questionário sobre dificuldades que incluíram questões sobre mensuração da glicemia, de seguimento do plano alimentar e de aplicação de insulina. A coleta de dados foi realizada antes da consulta médica da endocrinologista, em um hospital do interior do Estado de São Paulo.

Resultados: Pelas dificuldades identificadas e variáveis cardiometabólicas os adolescentes avaliados estão com descontrole glicêmico, realizam o rodízio de insulina de forma incompleta e enfrentam diversas dificuldades diárias para realizar o tratamento adequado, sendo as maiores relatadas em relação a aplicação de insulina e alimentação adequada.

Conclusão: Adolescentes diabéticos do tipo 1 tem dificuldades de seguir as condutas terapêuticas orientadas, com destaque para o tratamento insulinoterápico e as propostas para mudanças de hábitos alimentares, por meio do seguimento de uma dieta. Estratégias necessitam ser oferecidas pelos profissionais da área de saúde a estes indivíduos para lidar melhor com estas dificuldades que afetam diretamente o curso da doença, e os deixam mais susceptíveis ao desenvolvimento de complicações.

Palavras-chave: diabetes mellitus, estilo de vida, avaliação em saúde, adolescentes. 